\title{
Salt Stress Induced Modulations in Growth, Compatible Solutes and Antioxidant Enzymes Response in Two Cultivars of Safflower (Carthamus tinctorius L. Cultivar TSF1 and Cultivar SM) Differing in Salt Tolerance
}

\author{
T. Vijayalakshmi ${ }^{1}$, A. S. Vijayakumar ${ }^{1}$, K. Kiranmai', A. Nareshkumar², Chinta Sudhakar ${ }^{\text {* }}$ \\ ${ }^{1}$ Department of Botany, Sri Krishnadevaraya University, Anantapur, India \\ ${ }^{2}$ Department of Crop Physiology, GKVK, Bangalore, India \\ Email: *chintasudhakar@yahoo.com
}

How to cite this paper: Vijayalakshmi, T., Vijayakumar, A.S., Kiranmai, K., Nareshkumar, A. and Sudhakar, C. (2016) Salt Stress Induced Modulations in Growth, Compatible Solutes and Antioxidant Enzymes Response in Two Cultivars of Safflower (Carthamus tinctorius $\mathrm{L}$. Cultivar TSF1 and Cultivar SM) Differing in Salt Tolerance. American Journal of Plant Sciences, 7, 1802-1819. http://dx.doi.org/10.4236/ajps.2016.713168

Received: August 5, 2016

Accepted: September 25, 2016

Published: September 28, 2016

Copyright $\odot 2016$ by authors and Scientific Research Publishing Inc. This work is licensed under the Creative Commons Attribution International License (CC BY 4.0).

http://creativecommons.org/licenses/by/4.0/

(c) (†) Open Access

\begin{abstract}
Safflower is an important, traditional, multipurpose oil crop. This was to investigate the effect of different salinity levels on morphological, physiological, biochemical and antioxidant response of two safflower cultivars (Carthamus tinctorius L. cultivar TSF1 and cultivar SM) differing in salt tolerance. Salinity stress $(0.0 \%, 1.0 \%, 1.5 \%$ and $2.0 \%$ of $\mathrm{NaCl}$ ) was induced to safflower plants after 19 days of vegetative growth. After 12 days of stress imposition, plants were harvested and analysed for various parameters. The results revealed that cultivar TSF1 showed maximum growth, dry weight, cell membrane stability and more water content in both root and leaf tissues at higher salinity levels than cultivar SM. Salt stress resulted an accumulation of more soluble sugars, amino acids, proline and glycine betaine at high salinity level confers the tolerance potential of cultivar TSF1 over cultivar SM. Salt stress induces more increase in the enzyme activity of superoxide dismutase, ascorbate peroxidase, guaiacol peroxidase and catalase in tolerant cultivar than sensitive one. The results indicate that each cultivar adopt specific strategy at distinct salinity level for resistance against salinity. The possible conclusion is that improved tolerance in cultivar TSF1 to salinity may be accomplished by better management of growth, physiological attributes and antioxidative defence mechanisms.
\end{abstract}

\section{Keywords}

Safflower, Salinity Stress, Compatible Solutes, Antioxidative Enzymes 


\section{Introduction}

Soil salinity threatens agricultural economy as well as causes the shrinking of cultivable land [1] [2]. Salinity mainly occurs in arid and semi-arid conditions [3] where the precipitation is not enough to leach the excess of soluble salts from the root zone and poor quality of water is used for irrigation [4] and more than 60 million hectares of cultivable land throughout the World affected by salinity problem [5].

The primary response of plants to salt stress is an osmotic adjustment. Compatible solutes accumulation in the cytoplasm was observed in plants under salinity stress to balance ions in the vacuole [6]. These compatible solutes have a low molecular mass that does not affect to normal biochemical process. This includes proline, glycine betaine [7], sugars [8] and polyols [9]. The accumulation of various compatible solutes is considered as one of the protection strategies, through different processes, including maintenance of water economy at the cellular level, protection of membrane integrity, reactive oxygen species detoxification, and stabilisation of proteins in salt stressed plants [10]. Salinity induced ROS accumulation within plant cells is well known and that led to oxidative damage to membrane lipids, proteins and nucleic acids [11] [12]. An efficient system of enzymatic and non-enzymatic antioxidants is involved in scavenging ROS [12] [13]. These ROS affect lipid per oxidation, protein denaturation and DNA mutation [14]. ROS can be scavenged enzymatically by CAT, APX, GPX and SOD; non-enzymatically by low molecular weight antioxidants ascorbate, glutathione etc., Antioxidants up-regulation was observed in salt tolerant cultivars of tomato, pea, Jatropha, and Calendula [15]-[18], which suggests a suitable role of antioxidants in mitigating salt stress-induced oxidative damage.

Safflower (Carthamus tinctorius L.) is a traditional multipurpose and prospective oil seed crop and cultivated in irrigated arid and semiarid regions where soil salinity threats to agriculture [19]. Selection for salt-tolerant cultivars and identification of reliable simple genetic markers for salt tolerance has proven to be an important target for plant breeders, plant physiologists, and cellular and molecular biologists [20]. In view of tolerance potential and economic value of safflower, the present study was undertaken to assess tolerant potential of two safflower cultivars with respect to growth response, osmotic adjustment and antioxidative efficacy subjected to salinity stress for sustaining safflower cultivation. So the objective of this study was to assess various morphological, physiological, biochemical changes and antioxidative responses associated with the two cultivars subject to different salinity levels during vegetative growth.

\section{Materials and Methods}

\subsection{Plant Material and Salinity Treatment}

Safflower seeds (cultivars TSF1 and SM) procured from Tanduru ARS (Rangareddy District India) were sown in earthen pots containing red soil and farmyard manure (3:1). The pots were kept under natural photoperiod in the botanic garden, treated with 
water once a day and maintained for 19 days. Nineteen day-old plants were subjected to salt stress by adding 0 (control), $1.0 \%, 1.5 \%$ and $2.0 \% \mathrm{NaCl}$ solutions to the potted plants. For each treatment, twenty pots, each with three plants were maintained; control and treated pots were maintained daily with tap water. Care was taken to avoid leaching out of soluteion by adding water slightly less than field capacity. After 12 days of stress imposition, the leaves and roots were separated and stored in liquid nitrogen at $-80^{\circ} \mathrm{C}$ until further use.

\subsection{Growth Parameters}

The plants were carefully uprooted from pots and washed immediately with running tap water. Plant growth was determined by measuring the length of the root and shoot. The dry weight (DW) was measured after drying the uprooted plants at $80^{\circ} \mathrm{C}$ for $48 \mathrm{hrs}$.

\subsection{Relative Water Content (RWC)}

The leaf samples were washed with deionised water, blotted dry and fresh weights (FW) recorded. The leaves were immersed in distilled water for $4 \mathrm{hrs}$, blotted dry and the turgid weight (TW) was taken. The leaves were kept at $80^{\circ} \mathrm{C}$ in a hot air oven for $48 \mathrm{hrs}$ and dry weights (DW) were recorded. RWC was calculated according to Turner, [21] using the formula RWC $=\mathrm{FW}-\mathrm{DW} / \mathrm{TW}-\mathrm{DW} \times 100$.

\subsection{Total Sugars}

The reducing sugars were estimated by Nelson's method [22], as modified by Somogyi [23]. $1 \mathrm{ml}$ of alcoholic extract was taken into a test tube. To this $1.0 \mathrm{ml}$ of a freshly prepared mixture of 25 parts of reagent " $A$ " and 1 part of reagent " $B$ " (25:1) was added and mixed with the solutions. The test tubes were incubated in a boiling water bath for $20 \mathrm{~min}$ and cooled under a running tap water. $1 \mathrm{ml}$ of arsenomolybdate reagent was added. The colour developed very rapidly. The mixture was diluted to $10.0 \mathrm{ml}$ after $15 \mathrm{~min}$ and the absorbance was measured in a UV-Visible Spectrophotometer (Shimadzu-1601) at $500 \mathrm{~nm}$. Reagent blanks were used to adjust absorbance to zero. Reducing sugar content was estimated by using a standard curve prepared with dextrose.

\subsection{Free Proline}

Free proline content of control and $\mathrm{NaCl}$ treated samples was determined by following Bates [24] method. Fresh plant material (0.5 g) was homogenized in a pre-chilled mortar with a pestle using $3 \%$ aqueous sulfosalicylic acid. The homogenate was filtered through four layered muslin cloth and the filtrate was collected. The extraction was repeated twice, all the filtrates were pooled and made up to known volume. $2 \mathrm{ml}$ of the filtrate was taken into a test tube and $2 \mathrm{ml}$ of acid ninhydrin, $2 \mathrm{ml}$ of glacial acetic acid were added. The tubes were incubated at $100^{\circ} \mathrm{C}$ for $1 \mathrm{~h}$ in boiling water bath. After incubation, they were transferred to an ice bath to termi- 
nate the reaction. $4 \mathrm{ml}$ of toluene was added to the contents of the tubes and mixed thoroughly using a cyclomixer (CM101, REMI India) for $15 \mathrm{sec}$. Chromophore containing toluene was aspirated from the aqueous phase. Then the absorbance was measured in a UV-spectrophotometer at $520 \mathrm{~nm}$ against toluene. Proline was measured from the standard curve prepared with authentic proline and its amount was calculated on dry weight basis.

\subsection{Estimation of Ascorbic Acid (AsA)}

The measurement of total AsA was carried out as described by Cakmak and Marschner [25]. Fresh leaf samples $(500 \mathrm{mg}$ ) were extracted with $5 \mathrm{ml}$ of $5 \%$ metaphosphoric acid and centrifuged at $15,000 \times \mathrm{g}$ for $15 \mathrm{~min}$. The reaction mixture contained $0.2 \mathrm{ml}$ aliquot, $0.5 \mathrm{ml} 150 \mathrm{mM}$ phosphate buffer with $\mathrm{pH} 7.4$ having $5 \mathrm{mM}$ EDTA, $0.1 \mathrm{ml} 10 \mathrm{mM}$ DTT and $0.1 \mathrm{ml} \mathrm{0.5 \% (w/v)} \mathrm{N-ethylmaleimide} \mathrm{to} \mathrm{remove} \mathrm{excess} \mathrm{DTT.} \mathrm{10 \%} \mathrm{TCA,} \mathrm{44 \%}$ orthophosphoric acid, 2.1 bipyridine in $70 \%$ ethanol ( $0.4 \mathrm{ml}$ each) and $0.2 \mathrm{ml} \mathrm{3 \%} \mathrm{FeCl} 3$ were added to that mixture for the development of colour. The mixtures were then incubated in a water bath at $40^{\circ} \mathrm{C}$ for $40 \mathrm{~min}$ and the colour developed was read at 525 $\mathrm{nm}$. AsA was used as a standard and the concentration of AsA was expressed as $\mu \mathrm{mol} \cdot \mathrm{g}^{-1}$ dry weight.

\subsection{Glycine Betaine (GB)}

QACs were extracted and estimated according to Grieve and Grattan, [26]. Dried finely ground plant material (0.5 gm) was mechanically shaken with $20 \mathrm{ml}$ of deionized water for $24 \mathrm{hrs}$ at $25^{\circ} \mathrm{C}$. The samples were then filtered and the filtrates were diluted (1:1) with $2 \mathrm{~N} \mathrm{H} 2 \mathrm{SO} 4$. Aliquots $(0.5 \mathrm{ml})$ were taken into centrifuge tubes and cooled in ice water for $1 \mathrm{hr}$. Cold KI-I2 reagent $(0.2 \mathrm{ml})$ was added and then reactants were gently stirred. The tubes were stored at $4^{\circ} \mathrm{C}$ for $16 \mathrm{hrs}$ and then centrifuged at $10,000 \mathrm{rpm}$ for $15 \mathrm{~min}$ at $0^{\circ} \mathrm{C}$. The supernatant was carefully aspirated with a fine tipped glass tube. The periodide crystals were dissolved in $9.0 \mathrm{ml}$ of 1, 2-dichloroethane and mixed vigorously. After 2 hrs the absorbance was measured at $365 \mathrm{~nm}$ by using a spectrophotometer. Reference standards of glycine betaine $(50-200 \mu \mathrm{g} / \mathrm{ml})$ were prepared in $1 \mathrm{~N} \mathrm{H}_{2} \mathrm{SO}_{4}$. The amount of glycine betaine was calculated using following formula:

Glycine betaine content $=(\mathrm{A} 525-0.0121) / 0.035 \times 1.5 \times 25 / 0.5$.

\subsection{In Situ Histochemical Localization}

In situ accumulation of $\mathrm{O}_{2}^{--}$and $\mathrm{H}_{2} \mathrm{O}_{2}$ was detected by histochemical staining with NBT and DAB according to Romero-Puertas [27], with minor modifications. For $\mathrm{O}_{2}^{--}$detection the leaves of control and salt-stressed plants were excised and immersed in a $0.1 \%$ solution of NBT in $10 \mathrm{mM}$ phosphate buffer ( $\mathrm{pH} 7.8$ ). The leaves immersed were illuminated for $1-2 \mathrm{~h}$ until the appearance of dark spots, specific to blue formazan precipitates. For localization of $\mathrm{H}_{2} \mathrm{O}_{2}$ excised leaves were immersed in $10 \mathrm{mM}$ phosphate buffer ( $\mathrm{pH} 3.8$ ) solution containing $0.1 \% \mathrm{DAB}$ and then incubated 
at room temperature for $8 \mathrm{~h}$ until brown spots, appear by the reaction of DAB with $\mathrm{H}_{2} \mathrm{O}_{2}$. The leaves were then bleached in warm ethanol to visualize the blue and brown spots.

\subsection{Superoxide Anion $\left(\mathrm{O}_{2}^{--}\right)$Estimation}

Superoxide anion content was determined using the method described by Doke [28]. The leaves were cut into pieces and placed in the test tubes filled with $7 \mathrm{ml}$ of a mixture containing $50 \mathrm{mM}$ of $\mathrm{NaN}_{3}$ and incubated in dark for $5 \mathrm{~min}$. Then $2 \mathrm{ml}$ of the solution was taken from the tubes and heated for $15 \mathrm{~min}$ at $85^{\circ} \mathrm{C}$. The samples were cooled on ice for $5 \mathrm{~min}$ and the absorbance was measured at $580 \mathrm{~nm}$.

\subsection{Hydrogen Peroxide $\left(\mathrm{H}_{2} \mathrm{O}_{2}\right)$}

The estimation was done according to Singh [29]. Fresh leaves $(0.1 \mathrm{~g})$ were extracted in ice bath with $5 \mathrm{ml} 0.1 \%(\mathrm{w} / \mathrm{v}) \mathrm{TCA}$. The homogenate was centrifuged at $12,000 \times \mathrm{g}$ for $15 \mathrm{~min}$ and the supernatant $(0.5 \mathrm{ml})$ was added to $0.5 \mathrm{ml}$ of $10 \mathrm{mM}$ potassium phosphate buffer ( $\mathrm{pH} 7.0$ ) and $1 \mathrm{ml}$ of $1 \mathrm{M} \mathrm{KI} . \mathrm{H}_{2} \mathrm{O}_{2}$ concentrations of the samples were calculated and expressed in $\mu \mathrm{mol} \cdot \mathrm{g}^{-1}$ dry weight by using $\mathrm{H}_{2} \mathrm{O}_{2}$ as a standard.

\subsection{Lipid Peroxidation}

MDA the product of Lipid peroxidation was determined by estimating thiobarbituric acid reactive substances (TBARS) as described by Hodges et al. [30]. $500 \mathrm{mg}$ of leaf tissue was ground to a fine paste with $15 \mathrm{ml}$ of ethanol: water $(95: 5 \mathrm{v} / \mathrm{v}$ and $0.1 \%$ butylated hydroxyl toluene) the supernatant was collected after centrifugation $3000 \times \mathrm{g}$ for 10 min. Later the supernatant $(1 \mathrm{ml})$ was added to $20 \%$ TCA $(1 \mathrm{ml})$ along with $0.65 \%$ thiobarbituric acid (TBA) in a clean glass tube and mixed vigorously. Another $1 \mathrm{ml}$ of supernatant was treated with $1 \mathrm{ml}$ of $20 \%$ TCA and mixed vigorously. The solution was heated at $95^{\circ} \mathrm{C}$ for $30 \mathrm{~min}$ in a water bath, cooled immediately by ice then centrifuged at $3000 \times \mathrm{g}$ for $10 \mathrm{~min}$. Absorbance at $532 \mathrm{~nm}$ was recorded for MDA. In addition, the absorbance at $440 \mathrm{~nm}$ (carbohydrates) and $600 \mathrm{~nm}$ (phenylpropanoid pigments) was also recorded to avoid overestimation of MDA.

$$
\begin{aligned}
& {[(\text { Abs532 }+ \text { TBA })-(\text { Abs600 }+ \text { TBA })-(\text { Abs532 }-\mathrm{TBA})-(\text { Abs600 }-\mathrm{TBA})]=\mathrm{A} .} \\
& {[(\text { Abs440 }+\mathrm{TBA}-\mathrm{Abs600}+\mathrm{TBA}) 0.0571]=\mathrm{B} .} \\
& {\left[\text { MDA equivalents }\left(\mu \mathrm{mol} \cdot \mathrm{ml}^{-1}\right)=(\mathrm{A}-\mathrm{B} / 157000) 103\right]=\mathrm{C}} \\
& \text { MDA equivalents }\left(\mu \mathrm{mol} \cdot \mathrm{g}^{-1}\right)=(\mathrm{C} \times 15 \times 1 / 0.5) .
\end{aligned}
$$

\subsection{Cell Membrane Stability (CMS)}

Cell membrane stability measured according to the method of Premchandra et al., [31]. 30 leaf discs of $0.75 \mathrm{~cm}$ diameter were cut from healthy plants of both cultivars using a leaf punch and were placed into a $100 \mathrm{ml}$ conical flask and washed thrice with deionized distilled water. Leaf discs were submerged in $30 \mathrm{ml}$ of $1 \%, 1.5 \%$ and $2 \% \mathrm{NaCl}$ solutions for $24 \mathrm{hrs}$ at $100^{\circ} \mathrm{C}$. Discs submerged in distilled water served as controls. Both control and salt induced discs were dipped in $30 \mathrm{ml}$ of deionized distilled water for 24 
hrs at $100^{\circ} \mathrm{C}$, the flasks were warmed to $25^{\circ} \mathrm{C}$ shaken thoroughly and electrical conductivity was measured using an electrical conductivity meter $\left(\mathrm{C}_{1}\right.$ and $\left.\mathrm{T}_{1}\right)$. Following the conductivity measurements, the leaf tissues were killed by autoclaving for $15 \mathrm{~min}$, at 15 $\mathrm{lbs} / \mathrm{cm}^{3}$, cooled to $25^{\circ} \mathrm{C}$ and electrical conductivity was measured $\left(\mathrm{C}_{2}\right.$ and $\left.\mathrm{T}_{2}\right)$. Cell membrane stability of the leaf tissues was calculated as per the membrane percentage injury from the following equation:

Percentage membrane injury $=1-\left(1-\mathrm{T}_{1} / \mathrm{T}_{2}\right) /\left(1-\mathrm{C}_{1} / \mathrm{C}_{2}\right) \times 100$.

\subsection{Antioxidant Enzyme Assays}

Fresh leaf tissue was homogenized in $50 \mathrm{mM}$ Tris- $\mathrm{HCl}$ ( $\mathrm{pH}$ 7.5) buffer containing 40 $\mathrm{mM}$ phenyl methyl sulfonyl fluoride (PMSF), and $2 \%(\mathrm{w} / \mathrm{v})$ polyvinyl poly pyrrolidone (PVPP) with the addition of $2 \mathrm{mM}$ AsA for the APX assay. The extract was centrifuged at $15,000 \times \mathrm{g}$ for $20 \mathrm{~min}$ at $4^{\circ} \mathrm{C}$ and the resultant supernatant was used for all the enzyme assays. The amount of protein was calculated according to Lowry et al. [32]. All enzymatic activities were measured spectrophotometrically at $25^{\circ} \mathrm{C}$.

CAT (EC 1.11.1.6) activity was measured according to Beers and Sizer [33], with minor modifications. The decrease of $\mathrm{H}_{2} \mathrm{O}_{2}$ was monitored by reading the absorbance at $240 \mathrm{~nm}$ at the moment of $\mathrm{H}_{2} \mathrm{O}_{2}$ addition and 1 minute later. The difference in absorbance (DA240) was divided by the $\mathrm{H}_{2} \mathrm{O}_{2}$ molar extinction coefficient $\left(36 \mathrm{M}^{-1} \cdot \mathrm{cm}^{-1}\right)$ and the enzyme activity expressed as $\mathrm{mmol}$ of $\mathrm{H}_{2} \mathrm{O}_{2} \mathrm{~min}^{-1} \cdot \mathrm{mg}^{-1}$ protein.

APX (EC 1.11.1.1) activity was determined as described by the method of Nakano and Asada [34]. The oxidation of As A in the reaction mixture was measured using the rate of decrease in absorbance at $290 \mathrm{~nm}$ and was calculated using an extinction coefficient of $2.8 \mathrm{~m} \mathrm{M}^{-1} \cdot \mathrm{cm}^{-1}$.

GPX (EC 1.11.1.7) Guaiacol peroxidase (GPX) activity was determined in terms of oxidation of guaiacol by $\mathrm{H}_{2} \mathrm{O}_{2}$ [35] as measured by the increase in absorbance at 420 $\mathrm{nm}\left(\mathrm{E}=26.6 \mathrm{mM}^{-1} \cdot \mathrm{cm}^{-1}\right)$.

SOD (EC1.15.1.1) activity was assayed using the method described by Urbanek et al., [36]. One unit of SOD activity was defined as the amount of enzyme required to cause $50 \%$ inhibition of the NBT photo reduction rate.

\subsection{Statistical Analysis}

Data was analyzed by using the SPSS (Statistical Package for the Social Sciences) version 16.0. Data presented here are mean values and standard deviation $( \pm S D)$. One-way ANOVA was carried out using Post hoc multiple comparisons from Duncan's test at a significance level of $\mathrm{p}<0.05$.

\section{Results}

\subsection{Effect of Salinity on Plant Growth}

Root and shoot growth of two cultivars differed greatly to varied levels of salinity Figure 1(a). The percent decrease in root and shoot growth were 28.40 and 33.51 at $2 \%$ $\mathrm{NaCl}$ level in cultivar TSF1 and cultivar SM, respectively. At $1.5 \% \mathrm{NaCl}$ stress, a slight 
decrease was noticed in both cultivars when compared to control. Reduction in shoot growth was also in proportionate to $\mathrm{NaCl}$ stress levels. Comparatively, cultivar TSF1 maintained better root and shoot growth over cultivar SM even at high $\mathrm{NaCl}$ stress level.

\subsection{Effect of Salinity on Dry Matter}

$\mathrm{NaCl}$ salinity levels restricted the biomass of both cultivars Figure 1 (b). The reduction in biomass was more significant in cultivar SM than cultivar TSF1 in root and shoot at high salt stress levels, but insignificant reduction was observed in both cultivars at moderate $\mathrm{NaCl}$ stress.

\subsection{Effect of Salinity on Leaf Relative Water Content (RWC)}

Salinity effects relative water content of leaf in two cultivars; but the effect was more pronounced at high salinity. There was a gradual decline in leaf water content Figure 1(c). The percent decrease were 13, 15 and 20.4 in cultivar TSF1 ; while they were 15, 34 and 42 in cultivar $\mathrm{SM}$ at $1 \%, 1.5 \%$, and $2 \% \mathrm{NaCl}$ respectively, when compared with the control. This implies the cultivar TSF1 maintained more tissue water content even at high salinity level than SM.

\subsection{Effect of Salinity on Total Soluble Sugars}

The increase in sugars content was observed in root and leaf tissues in both cultivars at all stress levels. The percent increase was relatively more in cultivar TSF1 than in cultivar SM Figure 1(d). The degree of increase in soluble sugar content was dependent on the severity of stress in both cultivars, but with greater accumulation of soluble sugar content in cultivar TSF1 than in cultivar SM.

\subsection{Free Proline Content}

There was a proportionate increase of free proline content with stress intensity was ob-served in both cultivars. The percent increase was 72.7 and 51.1 in cultivar TSF1 and in cultivar $\mathrm{SM}$ at high $\mathrm{NaCl}$ stress. Maintenance of better proline accumulation supports the tolerance potential of cultivar TSF1 Figure 2(a).

\subsection{Effect of Salinity on Ascorbic Acid (AsA)}

Salinity affected AsA content at all regimes of $\mathrm{NaCl}$ stress but significantly in cultivar TSF1 than cultivar SM at 2\% $\mathrm{NaCl}$ stress Figure 2(b).

\subsection{Effect of Salinity on Glycine Betaine Content}

Accumulation of glycine betaine gradually increased with increasing stress level and the percent increase was more in cultivar TSF1 than in cultivar SM Figure 2(c).

\subsection{Effect of Salinity on $\mathrm{O}_{2}^{--}$and $\mathrm{H}_{2} \mathrm{O}_{2}$ Production}

Salinity induced $\mathrm{O}_{2}^{--}$and $\mathrm{H}_{2} \mathrm{O}_{2}$ content was observed in both cultivars at all levels of 
(a)

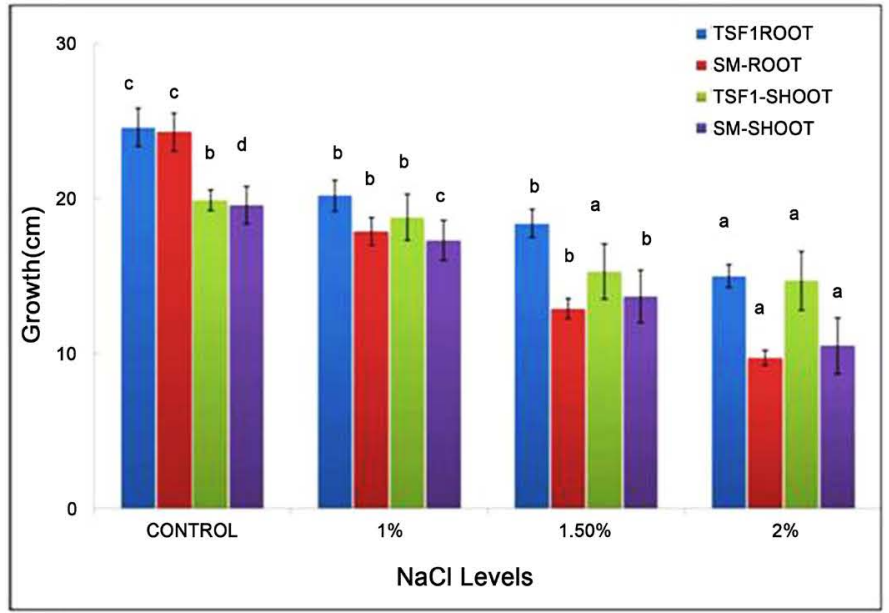

(c)

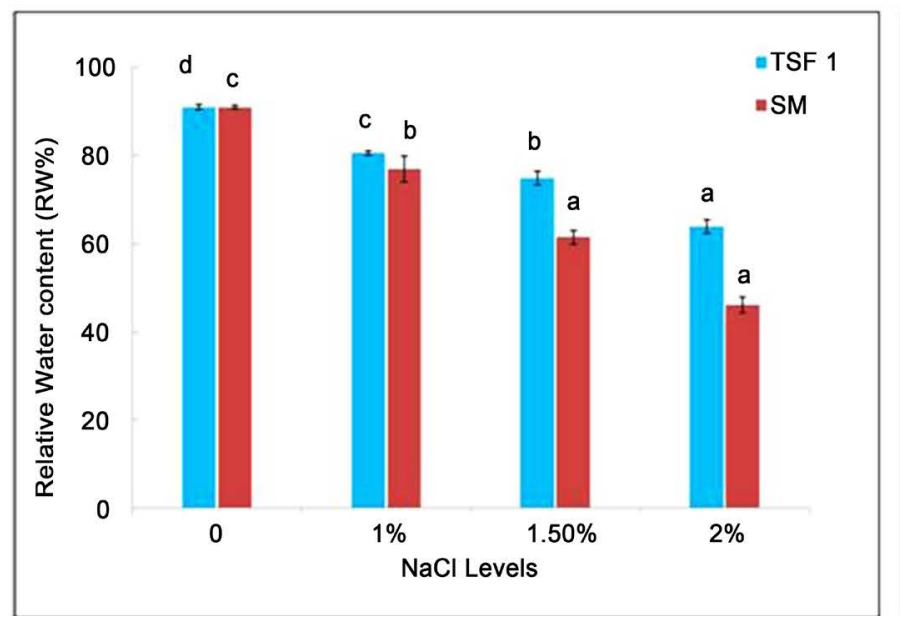

(b)

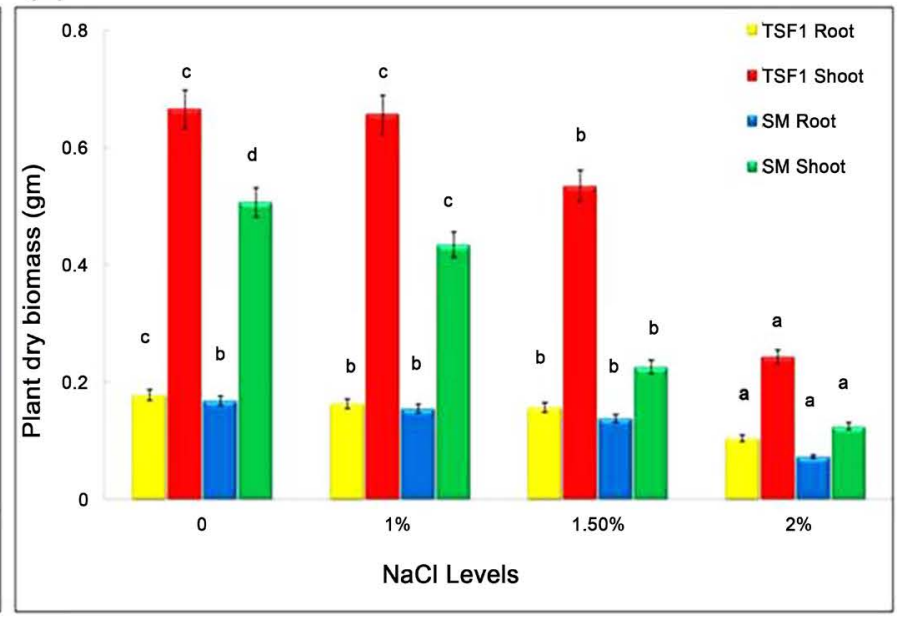

(d)

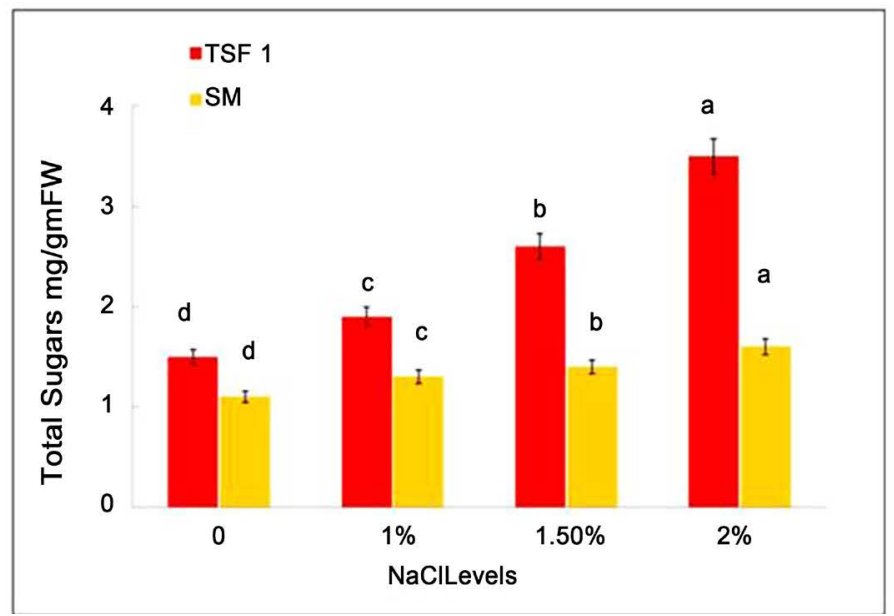

Figure 1. Effect of increasing concentrations of $\mathrm{NaCl}$ on (a) Plant growth $\left(\mathrm{cm} \cdot \mathrm{plant}^{-1}\right)$; (b) Plant biomass $\left(\mathrm{g} \cdot \mathrm{plant}^{-1}\right)$; (c) Relative water content (\%); (d) Total sugars (g.plant ${ }^{-1}$ ), values are means of three replicates and significant differences between means, as a determined by duncan test $(\mathrm{p}<0.05)$, are indicated by different letters.

$\mathrm{NaCl}$ stress. However, a smaller increase in $\mathrm{O}_{2}^{--}$and $\mathrm{H}_{2} \mathrm{O}_{2}$ content was observed in cultivar TSF1at high salinity level conferring its efficient defensive mechanism than in cultivar SM (Figure 3(a), Figure 3(b)).

\subsection{Lipid per Oxidation (MDA Content)}

Malondialdehyde content Figure 3(c) of both cultivars was elevated due to salinity and the magnitude of elevation was concentration dependent in both the cultivars. However, the percent increase in MDA content was 31 and 67 in cultivar TSF1and in cultivar SM, respectively.

\subsection{Effect of Salinity on Cell Membrane Stability (CMS)}

The data was shown in terms of percent membrane injury. The per cent membrane in jury was relatively less in cultivar TSF1 than in cultivar SM indicating better membrane 
(a)

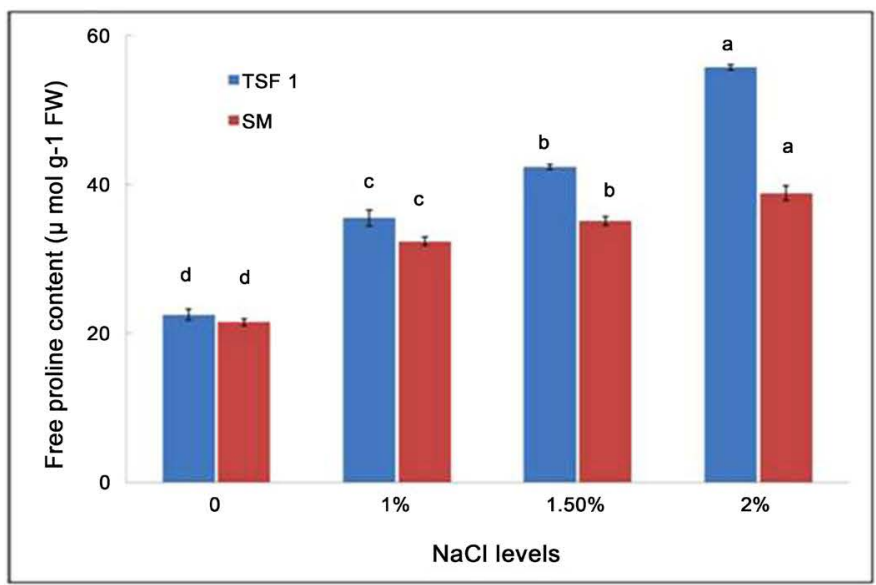

(c) (b)

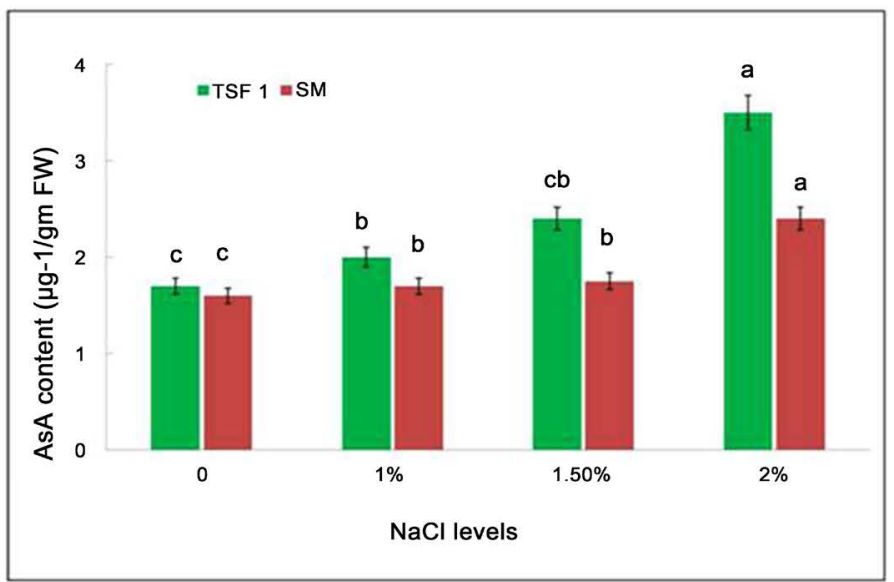

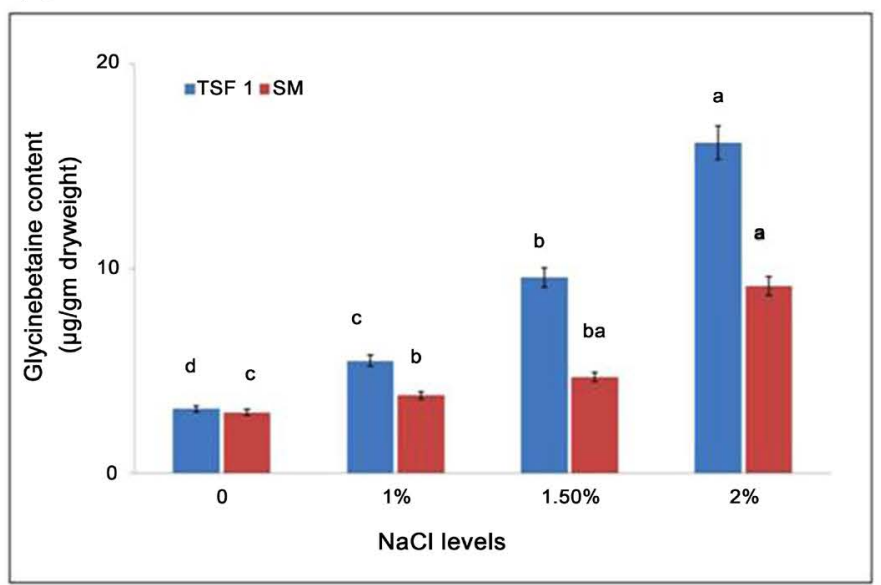

Figure 2. Effect of increasing concentrations of $\mathrm{NaCl}$ on (a) free proline content ( $\mu \mathrm{mol} \cdot \mathrm{g}^{-1} \mathrm{dw}$ ), (b) ascorbic acid content $\left(\mu \mathrm{mol} \cdot \mathrm{g}^{-1} \mathrm{dw}\right)$ (c) glycine betaine content of two safflower cultivars. Values are means of three replicates and significant differences between means, as a determined by duncan test $(\mathrm{p}<0.05)$, are indicated by different letters.

stability in that cultivar TSF1 Figure 3(d).

\subsection{Effect of Salinity on Antioxidant Enzyme Activities}

CAT activity was more in cultivar TSF1 than in cultivar SM at higher salinity gradient as depicted in Figure 4(a). Similarly, APX and GPX activities also increased with the gradual increase of stress intensity and this was more pronounced in cultivar TSF1 than in cultivar SM (Figure 4(b), Figure 4(c)). Salinity caused a significant increase in the total SOD enzyme activity with increased salinity stress in both cultivars, however percent increase was more in cultivar TSF1 than in cultivar SM (Figure 4(d), Figure 5).

\section{Discussion}

Growth promoted when treated with low concentrations of salts where as increased levels of salinity inhibited root and shoot growth. The inhibition could be due to specific ion toxicity on the rate of photosynthesis, enzyme activity and decreased levels of car- 
(a)

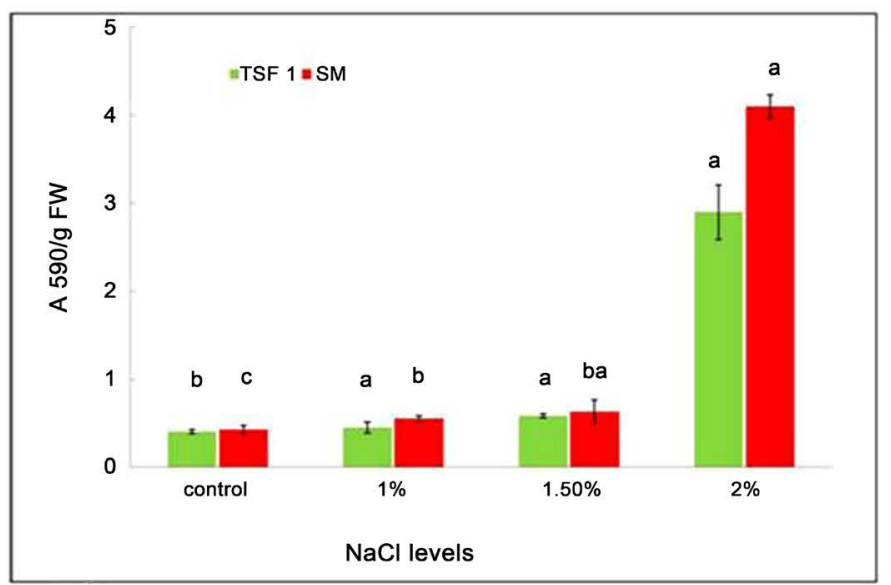

(c)

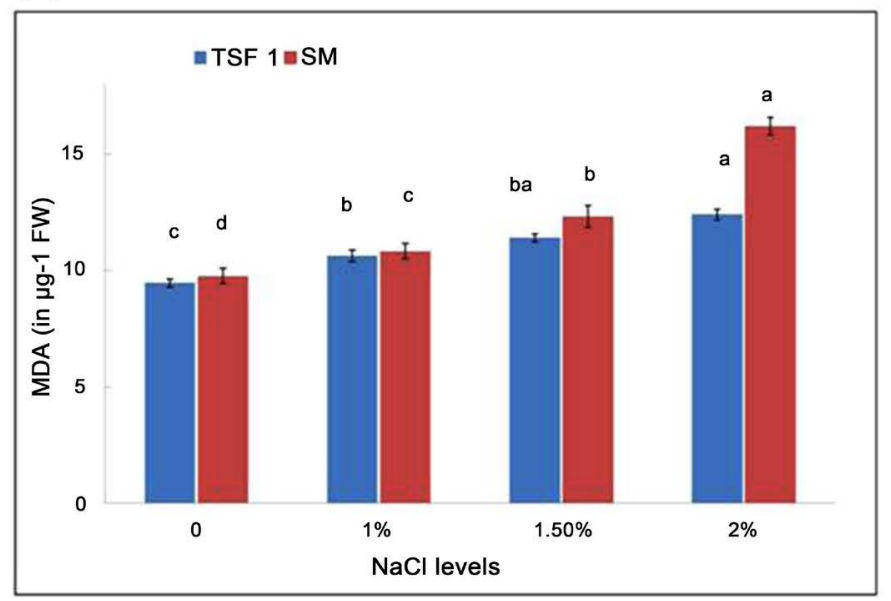

(b)

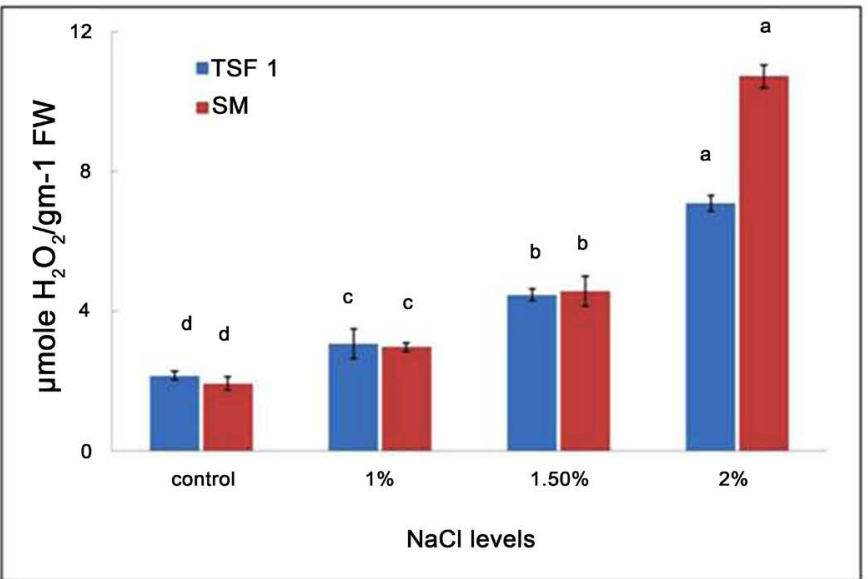

(d)

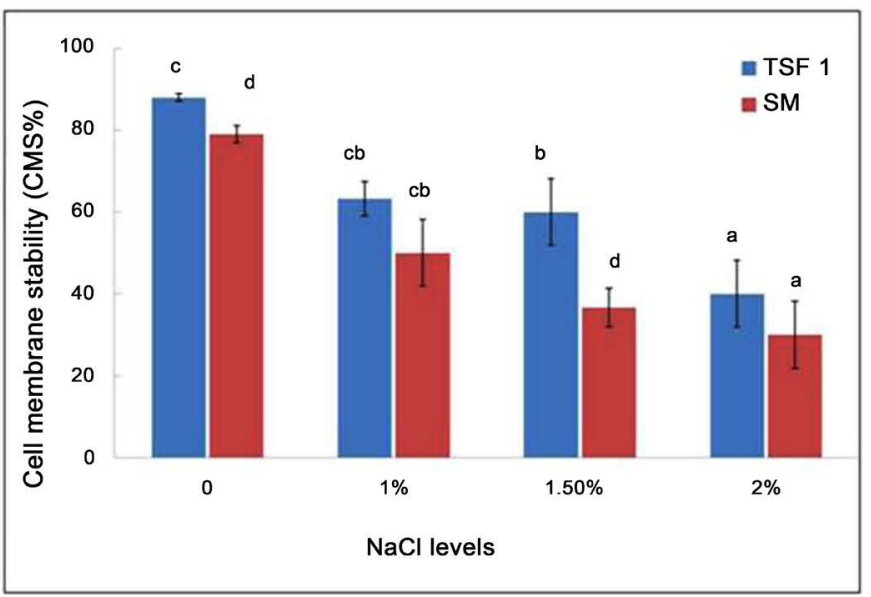

Figure 3. Effect of increasing concentrations of $\mathrm{NaCl}$ on (a) superoxide anion production (increase in od at $590 \mathrm{~nm} \cdot \mathrm{h} \cdot \mathrm{g}^{-1} \mathrm{dw}$ ); (b) hydrogen peroxide production ( $\left.\mu \mathrm{mol} \cdot \mathrm{g}^{-1} \mathrm{DW}\right)$; (c) malondialdehyde (MDA) content $\left(\mu \mathrm{mol} \cdot \mathrm{g}^{-1} \mathrm{DW}\right)$; (d) CMS (\%) (e) cat activity (in mol.g ${ }^{-1}$ $\mathrm{fw})$. Values are means of at least three replicates and significant differences between means, as determined by duncan test $(\mathrm{p}<0.05)$, are indicated by different letters.

bohydrates and growth hormones [37]. This was reflected in our results. At high salinity level cultivar SM showed more reduction in growth and biomass than cultivar TSF1. A significant reduction in biomass was observed at $1.5 \% \mathrm{NaCl}$ stress in both cultivars, but it was more pronounced at $2 \% \mathrm{NaCl}$ salinity. The reduction in growth and dry weight of different plants such as Plantago ovata and Plantago psyllium [38], Zea mays [39], Hordeum vulgare [40], Gossypium hirsutum [41] under salinity stress was observed previously. Synthesis and accumulation of organic solutes in plants is one of the important physiological responses of plants salinity, however as it consumes more energy which decreases in growth [38]. Usue [42] reported that a decrease in the growth of plants was not only a result of ions toxic effect but also a result of low water relations under salinity stress.

The decrease of leaf area due to salinity can be considered as an avoidance mechanism [43]. Enhancement of salinity in the root medium can lead to an osmotic adjustment 
(a)

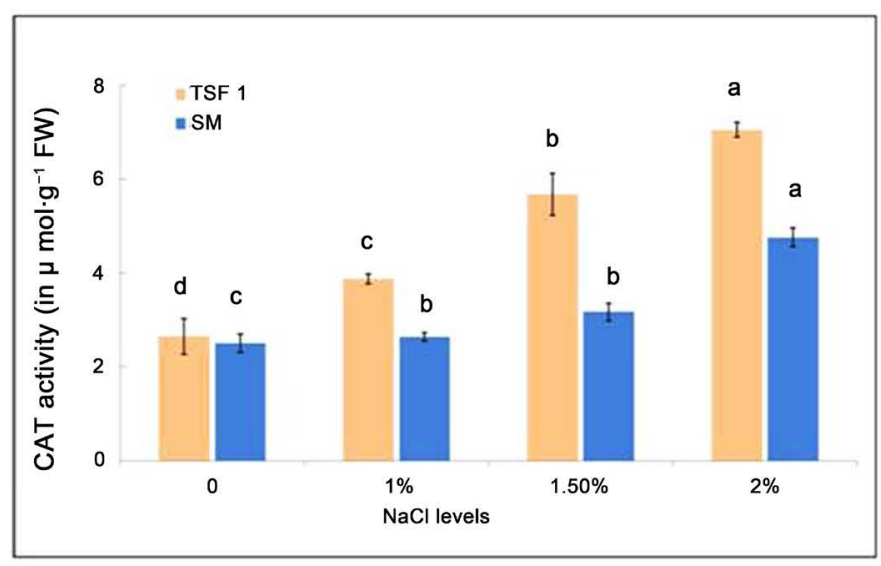

(c)

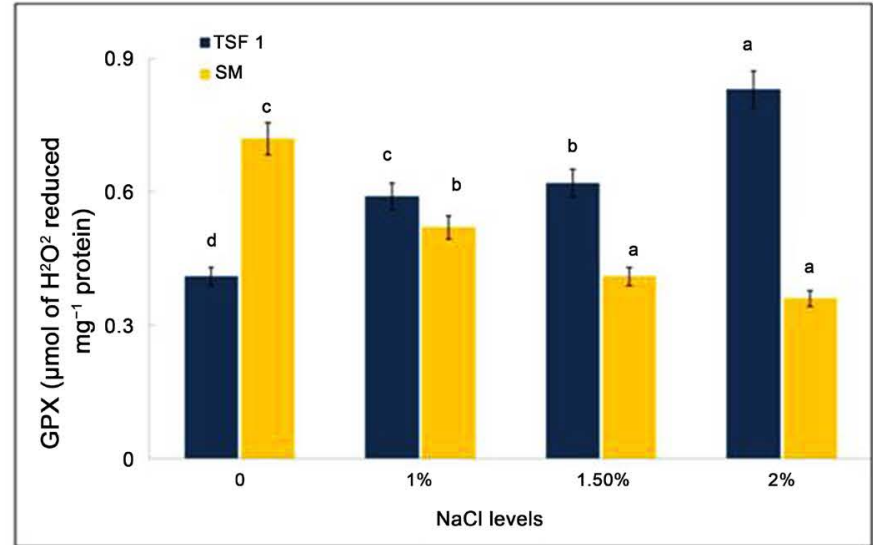

(b)

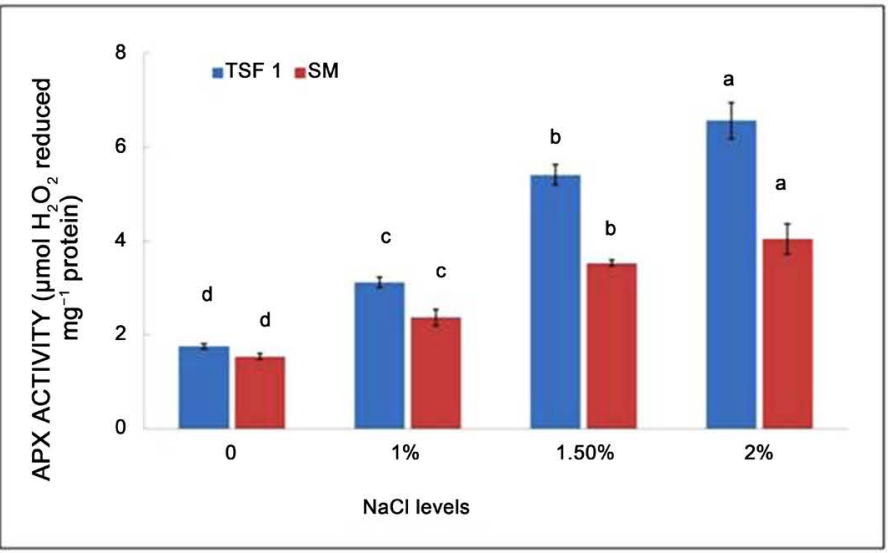

(d)

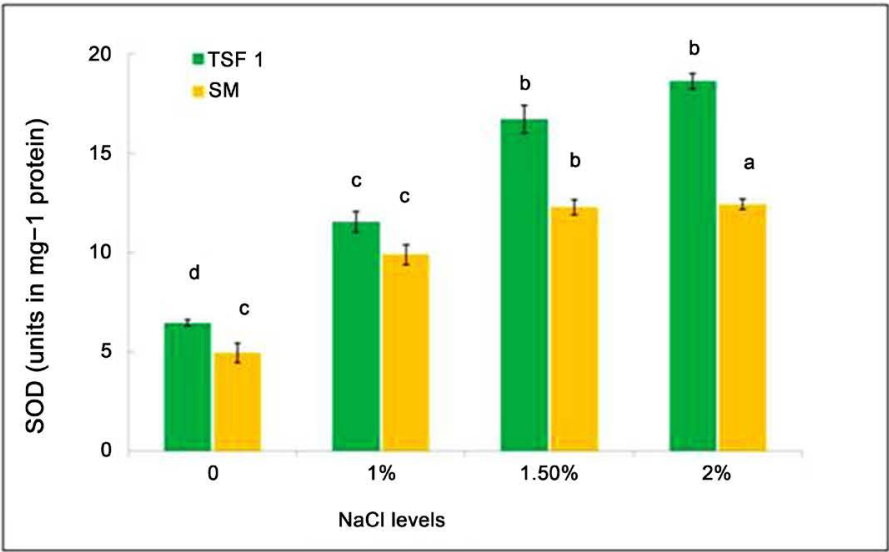

Figure 4. Effect of increasing concentrations effect of increasing concentrations of $\mathrm{NaCl}$ (a) CAT activity (in mol. $\mathrm{g}^{-1} \mathrm{FW}$ ); (b) APX Activity ( $\mu \mathrm{mol} \mathrm{H}_{2} \mathrm{O}_{2}$ reduced $\mathrm{mg}^{-1}$ protein); (c) $\mathrm{GPX}$ ( $\mu \mathrm{mol}$ of $\mathrm{H}_{2} \mathrm{O}_{2}$ reduced $\mathrm{mg}^{-1}$ protein); (d) SOD activity (units in $\mathrm{mg}^{-1}$ protein) of two safflower cultivars. Values are means of at least three replicates and significant differences between means, as determined by Duncan test $(\mathrm{p}<0.05)$, are indicated by different letters.

which is generally considered as an important tolerance to salinity. Safflower cultivar TSF1 responded to salinity by maintaining more leaf water content than cultivar SM, so it would be considered that cultivar TSF1 was more adaptable to salinity conditions than cultivar SM. Safflower cultivar TSF1 tend to maintain tissue water content even under increased salinity levels compared to cultivar SM. These results in agreement with Munns [44].

Carbohydrate accumulation, in plants tissue, is considered as an event of osmotic adjustment under stress [45]. The sugars render tolerance to salt stress either by serving as osmoticum or as respiratory substrates. Increasing of sugar content under salinity stress was reported in tomato [46] and barley [47]. Similar results were observed in present study that high salinity level accumulated more sugars in cultivar TSF1 than cultivar SM supporting its tolerance potential.

In addition, high level of carbohydrate status favoured proline accumulation [48]. Proline accumulation under stress serves for osmotic adjustment, integration of plasma 
Hydrogen peroxide $\left(\mathrm{H}_{2} \mathrm{O}_{2}\right)$ detection

(a)
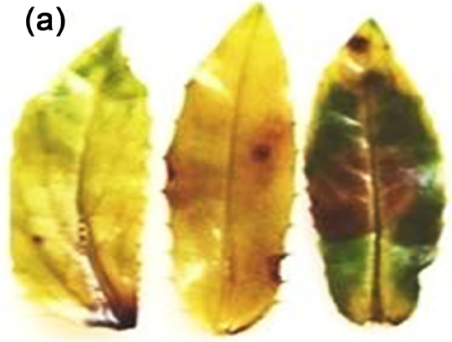

(c)

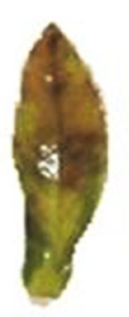

0

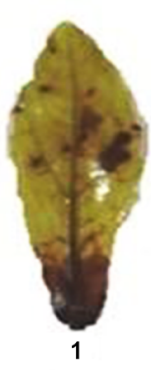

Salinity I

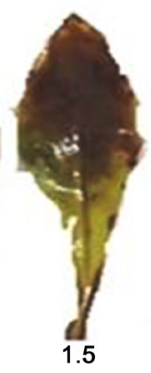

(\%)
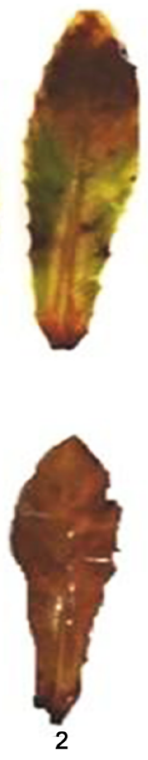

(b)

\section{Superoxide $\left(\mathrm{O}^{-}\right)$detection}

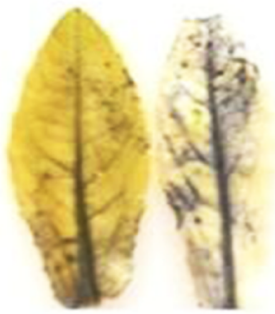

(d)

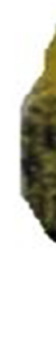

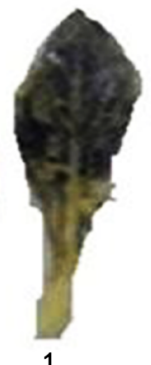
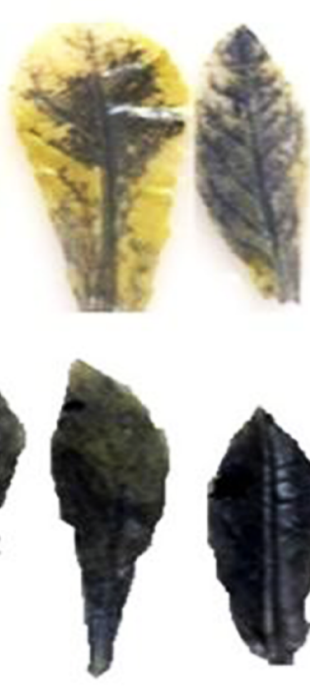

1.5

0 Salinity levels (\%)

Figure 5. Effect of increasing concentration of $\mathrm{NaCl}$ on free radical generation in cultivar TSF1 (a) (b) and cultivar SM (c) (d) leaves.

membrane, energy source, carbon and nitrogen source, free radical scavenger [45]. Many investigators have reported the high proline accumulation under salt stress in pigeon pea [49]. Sesamum indicum [50], barley [51], maize [52], jojoba plant [53] Higher accumulation of proline in cultivar TSF1 at high salinity levels confers its protective role against salt-induced osmotic disruption.

Reports infer that salinity decreased ascorbic acid content in wheat [54] in Linum usitatissimum [55] in wheat seedlings [56]. Increased ascorbic acid contents in salinity induced Hordeum vulgare plants was recorded by Sarwat et al. [57], in tomato fruits [58], in Cicer arietinum cultivar Abrodhi, [59] in tomato [60]. In the present study enhanced levels of ascorbic acid at high salinity were observed in tolerant cultivar TSF1 as compared to sensitive cultivar SM.

It has been demonstrated that the biosynthesis of GB is stress-inducible [61] and the level of accumulated GB is in correlated with the degree of salt tolerance [62]. In the present study cultivar TSF1 showed more increase GB content than cultivar SM under $\mathrm{NaCl}$ stress. In addition to its role as an osmoprotectant, GB has been reported to protect and stabilize PSII complex, as well as protect cell membranes and activation of enzymes in onion and rice [63] [64].

Plants under salt stress displayed an increase in the generation of $\mathrm{H}_{2} \mathrm{O}_{2}$ [65] as reported in the sensitive in cultivars of pea and rice [66] [67], which leads to membrane disruption, reflected in elevated electrolytes and MDA levels [11] [68] [69]. Excessive amounts of highly reactive $\mathrm{ROS}\left(\mathrm{H}_{2} \mathrm{O}_{2}\right.$ and $\left.\mathrm{O}_{2}^{--}\right)$can damage proteins, lipids and nucleic acids by oxidation [70]. TSF1 showed lower free radicals than the cultivar SM conferring its tolerance potential. 
MDA produced during peroxidation of membrane lipids, serves as an indicator of oxidative damage. High accumulation of MDA levels reported in the salt-sensitive rice cultivar as compared to tolerant [71]. This was in correlation with our results as tolerant cultivar TSF1 maintained low MDA levels than sensitive cultivar SM.

Cell membrane stability has been used to assess salt and drought stress tolerance by several investigators in mulberry [72] [73] and in wheat [74]. CMS values increased with increasing percentage of $\mathrm{NaCl}$ and with duration of treatment. The injury was more insensitive cultivar SM at high salinity level than tolerant cultivar TSF1. The maintenance of membrane integrity and thereby reducing the amount of solute leakage as a result of salt stress supports the tolerance nature of cultivar TSF1 over cultivar SM in correlation of previous reports [73].

High salinity induced oxidative stress in different plants [69]. The metabolism of reactive oxygen species depends on antioxidant enzymes, such as CAT, APX, GPX and SOD [75]. Superoxide dismutase reacts with superoxide radical at diffusion-limited rates to produce $\mathrm{H}_{2} \mathrm{O}_{2}$ [76]. The $\mathrm{H}_{2} \mathrm{O}_{2}$ produced by SOD is scavenged by peroxidases, especially Ascorbate peroxidase (APX), Guaiacol peroxidase (GPX) and catalase (CAT). In Mulberry cultivar, ascorbate peroxidase and catalase activity increased under salt stress [77]. Benavides et al. [78] reported that salt tolerance in two clones of potato (Solanum tuberosum) related to the antioxidant defence system. Low lipid peroxidation in salt-tolerant cultivar and higher increase in GPX activity as reported in earlier studies [79] correlating with our present result.

Leaves of salinity tolerant rice cultivars showed higher activities of SOD [69]. In contrast leaves of Calendula officinalis have less SOD activity under salinity control [16]. Similar findings were observed in the present study that the cultivar TSF1 showed more antioxidative enzyme activity even under high salinity stress indicating its efficient defensive mechanism.

The similar findings have been observed in our present study cultivar TSF1 showing better antoxidative enzyme efficacy than cultivar SM.

\section{Conclusion}

Our results suggest that the salinity stress induced oxidative damage by the generation of ROS and elevated MDA levels are counter-defenced by higher accumulation of non enzymatic (AsA, GB) and enzymatic antioxidative efficay (CAT, APX, GPX and SOD). Of the two cultivars TSF1 maintained better growth performance, enhanced compatible solutes (sugars, proline, AsA and Glycine betaine), and moreover efficient antioxidative enzyme activity over cultivar SM. These features support the efficient tolerance potential of cultivar TSF1 to salinity.

\section{Acknowledgements}

Financial support from Department of Science and Technology (DST: SR/SO/PS/0001/ 2011) is greatly acknowledged. 


\section{References}

[1] Ghassemi, F., Jackman, A.J. and Nix, A.H. (1995) Salinization of Land and Water Resources. $\mathrm{CAB}$ International, Wallingford.

[2] Munns, R. (2005) Genes and Salt Tolerance; Bringing Them Together. New Phytologist, 167, 645-663. http://dx.doi.org/10.1111/j.1469-8137.2005.01487.x

[3] Ehret, D.L. and Ho, L.C. (1986) The Effects of Salinityon Dry Matter Partitioning and Fruit Growth Intomatoes Grown in Nutrient Film Culture. Horticultural Science, 61, 361-367. http://dx.doi.org/10.1080/14620316.1986.11515714

[4] Mohammad, M., Shibli, R., Ajlouni, M. and Nimri, L. (1998) Tomato Roots and Shoots Responses to Salt Stress under Different Levels of Phosphorus Nutrition. Journal of Plant Nutrition, 21, 1667-1680. http://dx.doi.org/10.1080/01904169809365512

[5] Taffouo, V.D., Wamba, F.O., Youmbi, E., Nono, G.V. and Amougou, A. (2010) Growth, Yield, Water Status and Ionic Distribution Response of Three Bambara Groundnut [Vigna subterranea (L.) Verdc.] Landraces Grown under Saline Conditions. International Journal of Botany, 6, 53-58. http://dx.doi.org/10.3923/ijb.2010.53.58

[6] Zhifang, G. and Loescher, W.H. (2003) Expression of a Celery Mannose 6-Phosphate Reductase in Arabidopsis thaliana Enhances Salt Tolerance and Induces Biosynthesis of Both Mannitol and Aglucosyl-Mannitol Dimer. Plant Cell and Environment, 26, 275-283. http://dx.doi.org/10.1046/j.1365-3040.2003.00958.x

[7] Jaleel, A.C., Manivannan, P., Kishorekumar, A., Sankar, B. and Panneerselvam, R. (2007) Calcium Chloride Effects on Salinity-Induced Oxidative Stress, Proline Metabolism and Indole Alkaloid Accumulation in Catharanthus roseus. Comptes Rendus Biologies, 330, 674-683. http://dx.doi.org/10.1016/j.crvi.2007.07.002

[8] Kerepesi, I. and Galiba, G. (2000) Osmotic and Salt Stress-Induced Alteration in Soluble Carbohydrate Content in Wheat Seedlings. CropScience, 40, 482-487. http://dx.doi.org/10.2135/cropsci2000.402482x

[9] Bohnert, H.J., Nelson, D.E. and Jensen, R.G. (1995) Adaptations to Environmental Stresses. The Plant Cell, 7, 1099. http://dx.doi.org/10.1105/tpc.7.7.1099

[10] Ashraf, M. and Foolad, M.R. (2007) Roles of Glycine Betaine and Proline in Improving Plant Abiotic Stress Resistance. Environmental and Experimental Botany, 59, 206-216. http://dx.doi.org/10.1016/j.envexpbot.2005.12.006

[11] PérezLópez, U., Robredo, A., Lacuesta, M., Sgherri, C., Muñoz Rueda, A., Navari Izzo, F. and Menapetite A. (2009) The Oxidative Stress Caused by Salinity in Two Barley Cultivars Is Mitigated by Elevated $\mathrm{CO}_{2}$. Physiology of Plant, 135, 29-42. http://dx.doi.org/10.1111/j.1399-3054.2008.01174.x

[12] Gill, S.S. and Tuteja, N. (2010) Reactive Oxygen Species and Antioxidant Machinery in Abiotic Stress Tolerance in Crop Plants. Plant Physiology and Biochemistry, 48, 909-930. http://dx.doi.org/10.1016/j.plaphy.2010.08.016

[13] Karuppanapandian, T., Moon, J.C., Kim, C., Manoharan, K. and Kim, W. (2011) Reactive Oxygen Species in Plants: Their Generation, Signal Transduction, and Scavenging Mechanisms. Australian Journal of Cropsciences, 5, 709-725.

[14] Santia di Toppi, L. and Gabbrielli, R. (1999) Response to Cadmium in Higher Plants. Environmental and Experimental Botany, 42, 235-248. http://dx.doi.org/10.1016/s0098-8472(98)00058-6

[15] Hernandez, J.A., Jimenez, A., Mullineaux, P. and Sevilla, F. (2000) Tolerance of Pea [Pisumsativum L.] to Long-Term Salt Stress Is Associated with Induction of Antioxidant Defences. Plant Cell and Environment, 23, 853-862. 
http://dx.doi.org/10.1046/j.1365-3040.2000.00602.x

[16] Chaparzadeh, N.D., Amico, M.L., Khavari Nejad, R.A., Izzo, R. and NavariIzzo, F. (2004) Antioxidative Responses of Calendula Officinalis under Salinity Conditions. Plant Physiology and Biochemistry, 42, 695-701. http://dx.doi.org/10.1016/j.plaphy.2004.07.001

[17] Mittova, V., Guy, M., Tal, M. and Volokita, M. (2004) Salinity Up-Regulates the Antioxidative System in Root Mitochondria and Peroxisomes of the Wild Salt-Tolerant Tomatospecies Lycopersicon pennellii. Journal of Exprimental Botany, 55, 1105-1113. http://dx.doi.org/10.1093/jxb/erh113

[18] Gao, S., Ouyang, C., Wang, S., Xu, Y., Tang, L. and Chen, F. (2008) Effects of Salt Stress on Growth, Antioxidant Enzyme and Phenylalanine Ammonialyase Activities in Jatropha curcas L. Seedlings. Plant Soil and Environment, 54, 374-338.

[19] Kaya, C., Tuna, A.L. and Yokaş, I. (2009) The Role of Plant Hormones in Plants under Salinity Stress. Springer, Berlin, 45-50.

[20] Ekiz, H. and Yilmaz, A. (2003) Determination of the Salt Tolerance of Some Barley Genotypes and the Characteristics Affecting Tolerance. Turkish Journal of Agriculture and Forestry, 27, 253-260.

[21] Turner, N.C. (1981) Techniques and Experimental Approaches for the Measurement of Plant Water Status. Plant and Soil, 58, 339-366. http://dx.doi.org/10.1007/BF02180062

[22] Nelson, N. (1944) A Photometric Adaptation of the Somogyi Method for the Determination of Glucose. Journal of Biology and Chemistry, 153, 375-380.

[23] Somogyi, M.J. (1952) Notes on Sugar Determination. Journal of Biological Chemistry, 195, 19-23.

[24] Bates, L.S., Waldren, R.P. and Teare, E.D. (1973) Rapid Determination of Free Proline for Stress Studies. Plant and Soil, 39, 205-207. http://dx.doi.org/10.1007/BF00018060

[25] Cakmak, I. and Marschner, H. (1992) Magnesium Deficiency and High Light Intensity Enhance Activities of Superoxide Dismutase, Ascorbate Peroxidise and Glutathione Reductase in Bean Leaves. Plant Physiology, 98, 1222-1227. http://dx.doi.org/10.1104/pp.98.4.1222

[26] Grieve C.M. and Grottan, S.R. (1983) Rapid Assay for Determination of Water Soluble Quaternary Ammonium Compounds. Plant and Soil, 70, 303-307. http://dx.doi.org/10.1007/BF02374789

[27] Romero-Puertas, M.C., Rodriguez-Serrano, M., Corpas, F.J., Gomez, M., Del Rio, L.A. and Sandalio, L.M. (2004) Cadmium-Induced Sub-Cellular Accumulation of $\mathrm{O}_{2}{ }^{-}$and $\mathrm{H}_{2} \mathrm{O}_{2}$ in Pea Leaves. Plant Cell and Environment, 27, 1122-1134. http://dx.doi.org/10.1111/j.1365-3040.2004.01217.x

[28] Doke, N. (1983) Involvement of Superoxide Anion Generation in the Hypersensitive Response of Potato Tuber Tissues to Infection with an Incompatible Race of Phytophtora infestans and the Hyphal Wall Components. Physiology and Plant Pathology, 23, 345-357. http://dx.doi.org/10.1016/0048-4059(83)90019-X

[29] Singh, N., Ma, L.Q., Srivastava, M. and Rathinasabapathi, B. (2006) Metabolic Adaptations to Arsenic-Induced Oxidative Stress in Pteris vittata L. and Pteris ensiformis L. Plant Science, 170, 274-282. http://dx.doi.org/10.1016/j.plantsci.2005.08.013

[30] Hodges, D.M., DeLong, J.M., Forney, C.F. and Prange, R.K. (1999) Improving the Thiobarbituric Acid Reactive Substances Assay for Estimating Lipid Peroxidation in Plant Tissues Containing Anthocyanin and Other Interfering Compounds. Planta, 207, 604-611. http://dx.doi.org/10.1007/s004250050524

[31] Premachandra, G.S., Soneoka, H., Kanaya, M. and Ogata, S. (1991) Cell Membrane Stability and Leaf Surface Wax Content as Affected by Increasing Water Deficits in Maize. Journal of Experimental Botany, 42, 167-171. http://dx.doi.org/10.1093/jxb/42.2.167 
[32] Lowry, O.H., Rosebrough, N.J., Farr, A.L. and Randall, R.S. (1951) Protein Measurements with the Folin-Phenol Reagent. Journal of Biological Chemistry, 193, 265-275.

[33] Beers, R.F. and Seizer, I.W. (1952) Spectrophotometric Method for Measuring the Breakdown of Hydrogen Peroxide by Catalase. Journal of Biological Chemistry, 115, 133-140.

[34] Nakano, Y. and Asada, K. (1981) Hydrogen Peroxide Is Scavenged by Ascorbate-Specific Peroxidase in Spinach Chloroplasts. Plant and Cell Physiology, 22, 867-880.

[35] Upadhyaya, D., Sankhla, T.D., Davis, N., Sankhla, B.N. and Smith, J. (1985) Effect of Paclobutrazol on the Activities of Some Enzymes of Activated Oxygen Metabolism and Lipid Peroxidation in Senescing Soybean Leaves. Plant Physiology, 121, 453-461. http://dx.doi.org/10.1016/S0176-1617(85)80081-X

[36] Urbanek, H., Kuzniak Gebarowska, E. and Herka, K. (1991) Elicitation of Defence Responses in Bean Leaves by Botrytis cinerea Polygalacturonase. Acta Physiologiae Plantarum, 13, 43-50.

[37] Mazher, A.M.A., ElQuesni, E.M.F. and Farahat, M.M. (2007) Responses Ornamental and Woody Trees to Salinity. World Journal of Agricultural Sciences, 3, 386-395.

[38] Safarnejad, A., Salami, M. and Hamidi, H. (2007) Morphological Characterization of Medicinal Plants (Plantago ovata, Plantago psyllium) in Response to Salt Stress. Pajouhesh and Sazandegi, 75, 152-160.

[39] Turan, M.A., Elkrim, A.H.A., Taban, N. and Taban, S. (2010) Effect of Salt Stress on Growth and Ion Distribution and Accumulation in Shoot and Root of Maize Plant. African Journal of Agricultural Research, 5, 584-588.

[40] Innocenti, E.D., Hafsi, C., Guidi, L. and Navari. F. (2009) The Effect of Salinity on Photosynthetic Activity in Potassium-Deficient Barley Species. Journal of Plant Physiology, 66, 1968-1981.

[41] Rezaee, M.E., Khavarinejad, R.E. and Fahimi, H. (2004) Physiological Response of Cotton (Gossypium hirsutum L.) Plants to Soil Salinity. Pajouhesh and Sazandegi, 17, 81-89.

[42] Usue, P.L., Anabel, R., Matie, L., Amaia, M.P. and Alberto, M.R. (2009) The Impact of Salt Stress on the Water Statue of Barley Plants Partially Mitigated by Elevated $\mathrm{CO}_{2}$. Environmental and Experimental Botany, 66, 463470.

[43] Chaves, M.M., Flexas, J. and Pinheiro, C. (2008) Photosynthesis under Drought and Salt Stress: Regulation Mechanisms from Whole Plant to Cell. Annals of Botany, 103, 551-560. http://dx.doi.org/10.1093/aob/mcn125

[44] Munns, R. (2002) Comparative Physiology of Salt and Water Stress. Plant Cell Environment, 25, 239-250. http://dx.doi.org/10.1046/j.0016-8025.2001.00808.x

[45] Dhanapackiam, S. and Ilyas, M. (2010) Effect of Salinity on Chlorophyll and Carbo-Hydrate Contents of Sesbania grandiflora Seedlings. Indian Journal of Science and Technology, 3, 64-66.

[46] Amini, F. and Ehsanpour, A.A. (2005) Soluble Proteins, Proline, Carbohydrates and $\mathrm{Na}^{+} / \mathrm{K}^{+}$ Changes in Two Tomato (Lycopersicon esculentum Mill.). Cultivars under in Vitro Salt Stress. American Journal of Biochemistry and Biotechnology, 1, 204-208. http://dx.doi.org/10.3844/ajbbsp.2005.204.208

[47] Bagheri, A. and Sadeghipour, O. (2009) Effects of Salt Stress on Yield, Yield Components and Carbohydrates Content in Four Hull Less Barley (Hordeum vulgare L.) Cultivars. Journal of Biological Sciences, 9, 909-912. http://dx.doi.org/10.3923/jbs.2009.909.912

[48] Hanson, A.D. (1982) Metabolic Responses of Mesophytes to Plant Water Deficits. Annual Review of Plant Physiology, 33, 163-203.

http://dx.doi.org/10.1146/annurev.pp.33.060182.001115 
[49] Waheed, A., Hafiz, I.A., Qadir, G., Murtaza, G., Mahmood, T. and Ashraf, M. (2006) Effect of Salinity on Germination, Growth, Yield, Ionic Balance and Solute Composition of Pigeon Pea (Cajanus cajan (L.) Mill sp). Pakistan Journal of Botany, 38, 1103-1117.

[50] Koca, H., Bor, M., Ozdemir, F. and Turkan, I. (2007) The Effect of Salt Stress on Lipid Peroxidation, Antioxidative Enzymes and Proline Content of Sesame Cultivars. Environmental and Experimental Botany, 3, 344-351. http://dx.doi.org/10.1016/j.envexpbot.2006.12.005

[51] Sadeghi, H. (2009) Effects of Different Levels of Sodium Chloride on Yield and Chemical Composition in Two Barley Cultivars. American-Eurasian Journal of Sustainable Agriculture, 3, 314-320.

[52] Chaum, S. and Kirdmanee, C. (2009) Effect of Salt Stress on Proline Accumulation Photosynthetic Ability and Growth Characters in Two Maize Cultivars. Pakistan Journal of Botany, 41, 87-98.

[53] Fayek, M.A., Shabaan, E.A., Zayed, N.S., El-Obeidy, A.A. and Taha, R.A. (2010) Effect of Salt Stress on Chemical and Physiological Contents Jojoba (Simmondsia chinensis) Chneider Using in Vitro Culture. World Journal of Agricultural Science, 6, 446-444.

[54] Seth, S.P., Sharma, V. and Khandelwal, S.K. (2007) Effect of Salinity on Antioxidant Enzymes in Wheat. Indian Journal of Plant Physiology, 12, 186-188.

[55] Emam, M.M. and Helal, N.M. (2008) Vitamins Minimize the Salt-Induced Oxidative Stress Hazards. Australian Journal of Basic and Applied Sciences, 2, 1110-1119.

[56] Mandhania, S., Madan, S. and Sheokand, S. (2010) Differential Response in Salt Tolerant and Sensitive Genotypes of Wheat in Terms of Ascorbate, Carotenoides, Proline and Plant Water Relations. Asian Journal of Experimental Biological Sciences, 1, 792-797.

[57] Sarwat, M.I. and El-Sherif, M. (2007) Increasing Salt Tolerance in Some Barley Genotypes (Hordeum vulgare) by Using Kinetin and Benzyladenine. World Journal of Agricultural Sciences, 3, 617-629.

[58] Kim, H.J., Fonseca, J.M., Kubota, C., Kroggel, M. and Choi, J.H. (2008) Quality of Fresh-Cut Tomatoes as Affected by Salt Treatment in Irrigation Water and Post-Processing Ultraviolet-Treatment. Journal of the Science of Food and Agriculture, 88, 1969-1974. http://dx.doi.org/10.1002/jsfa.3305

[59] Mishra, M., Mishra, P.K., Kumar, U. and Prakash, V. (2009) NaCl Phytotoxicity Induces Oxidative Stress and Response of Antioxidant Systems in Cicer arietinum L. cv. Abrodhi. Botany Research International, 2, 74-82.

[60] Gautier, H., Lopez-Lauri, F., Massot, C., Murshed, R., Marty, I., Grasselly, D., Keller, C., Sallanon, H. and Genard, M. (2010) Impact of Ripening and Salinity on Tomato Fruit Ascorbate Content and Enzymatic Activities Related to Ascorbate Recycling. Functional Plant Science and Biotechnology, 4, 66-75.

[61] Sakamoto, A. and Murata, N. (2002) The Role of Glycine Betaine in the Protection of Plants from Stress: Clues from Transgenic Plants. Plant Cell Environment, 25, 163-171. http://dx.doi.org/10.1046/j.0016-8025.2001.00790.x

[62] Saneoka, H., Nagasaka, C., Hahn, D.T., Yang, W.J., Premachandra, G.S., Joly, R.J. and Rhodes, D. (1995) Salt Tolerance of Glycine Betaine-Deficient and Containing Maize Lines. Plant Physiology, 107, 631-638.

[63] Mansour, M.M.F. (1998) Protection of Plasma Membrane of Onion Epidermal Cells by Glycinebetaine and Proline against $\mathrm{NaCl}$ Stress. Plant Physiology and Biochemistry 36, 767772. http://dx.doi.org/10.1016/S0981-9428(98)80028-4

[64] Rahman, M.S., Miyake, H. and Takeoka, Y. (2002) Effect of Exogenous Glycinebetaine on Growth and Ultrastructure of Salt-Stressed Rice Seedlings (Oryza sativa L.). Plant Production Science, 5, 33-44. http://dx.doi.org/10.1626/pps.5.33 
[65] Roxas, V.P., Lodhi, S.A., Garrett, D.K., Mahan, J.R. and Allen, R.D. (2000) Stress Tolerance in Transgenic Tobacco Seedlings That Overexpress Glutathione S-Transferase Glutathione Peroxidase. Plant Cell Physiology, 41, 1229-1234. http://dx.doi.org/10.1093/pcp/pcd051

[66] Hernandeza, J., Maria, A. and Almansa, S. (2002) Short-Term Effects of Salt Stress on Antioxidant Systems and Leaf Water Relations of Pealeaves. Physiologia Plantarum, 115, 251 257. http://dx.doi.org/10.1034/j.1399-3054.2002.1150211.x

[67] Lee, D.H., Kim, Y.S. and Lee, C.B. (2001) The Inductive Responses of the Antioxidant Enzymes by Salt Stress in the Rice (Oryza sativa L.). Journal of Plant Physiology, 158, 737-745. http://dx.doi.org/10.1078/0176-1617-00174

[68] Sharma, P., Jha, A.B., Dubey, R.S. and Pessarakli, M. (2012) Reactive Oxygen Species, Oxidative Damage, and Antoxidative Defense Mechanism in Plants under Stressful Conditions. Journal of Botany, 2012, Article ID: 217037.

[69] Chawla, S., Jain S. and Jain, V. (2013) Salinity Induced Oxidative Stress and Antioxidant System in Salt-Tolerant and Salt-Sensitive Cultivars of Rice (Oryza sativa L.). Journal of Plant Biochemistry and Biotechnology, 22, 27-34. http://dx.doi.org/10.1007/s13562-012-0107-4

[70] Halliwell, B. and Gutteridge, J.M.C. (1985) Free Radicals in Biology and Medicine. Clarendon Press, Oxford.

[71] Roychoudhury, A., Basu, S. and Sengupta, D.N. (2011) Amelioration of Salinity Stress by Exogenously Applied Spermidine or Spermine in Three Varieties of Indica Rice Differing in Their Level of Salt Tolerance. Journal of Plant Physiology, 168, 317-328. http://dx.doi.org/10.1016/j.jplph.2010.07.009

[72] Giridarakumar, S., Madhusudan, K.V., Sreenivasulu, N. and Sudhakar, C. (2000) Stress Responses in Two Genotypes of Mulberry (Morus alba L.) under $\mathrm{NaCl}$ Salinity. Indian Journal of Experimental Biology, 38, 192-195.

[73] Sudhakar, C., Lakshmi, A. and Giridarakumar, S. (2001) Changes in the Antioxidant Enzyme Efficacy in Two High Yielding Genotypes of Mulberry (Morus alba L.) under $\mathrm{NaCl}$ Salinity. Plant Science, 161, 613-619. http://dx.doi.org/10.1016/S0168-9452(01)00450-2

[74] Farooq, S. and Azam, A.F. (2006) The Use of Cell Membrane Stability (CMS) Technique to Screen for Salt Tolerant Wheat Varieties. Journal of Plant Physiology, 163, 629-637. http://dx.doi.org/10.1016/j.jplph.2005.06.006

[75] Lee, D.H. and Lee, C.B. (2000) Chilling Stress Induced Changes of Antioxidant Enzymes in the Leaves of Cucumber: In Gel Enzymes Activity Assays. Plant Science, 159, 75-85. http://dx.doi.org/10.1016/S0168-9452(00)00326-5

[76] Serraz, R. and Sinclair, T.R. (2002) Osmolyte Accumulation Can It Really Help Increase Crop Yield under Drought Conditions? Plant Cell and Environment, 25, 333-341 http://dx.doi.org/10.1046/j.1365-3040.2002.00754.x

[77] Harinasut, P., Darinee, P., Roengmongkol, K. and Charoensataporn, R. (2003) Salinity Effects on Antioxidant Enzymes in Mulberry Cultivar. ScienceAsia, 29, 109-111 http://dx.doi.org/10.2306/scienceasia1513-1874.2003.29.109

[78] Benavides, P.M., Marconi, L.P., Gallego, M.S., Canba, E.M. and Tomaro, L.M. (2000) Relationship between Antioxidant Defence Systems and Salt Tolerance in Solanum tuberosum. Australian Journal of Plant Physiology, 27, 273-278.

[79] Yazici, I., Turkan, I., Sekmen, A.H. and Demiral, T. (2007) Salinity Tolerance of Purslane (Portulaca oleracea L.) Is Achieved by Enhanced Antioxidative System, Lower Level of Lipid Peroxidation and Proline Accumulation. Environmental Experimental Botany, 61, 4957. http://dx.doi.org/10.1016/j.envexpbot.2007.02.010 
Submit or recommend next manuscript to SCIRP and we will provide best service for you:

Accepting pre-submission inquiries through Email, Facebook, LinkedIn, Twitter, etc. A wide selection of journals (inclusive of 9 subjects, more than 200 journals)

Providing 24-hour high-quality service

User-friendly online submission system

Fair and swift peer-review system

Efficient typesetting and proofreading procedure

Display of the result of downloads and visits, as well as the number of cited articles

Maximum dissemination of your research work

Submit your manuscript at: http://papersubmission.scirp.org/

Or contact ajps@scirp.org 